\title{
STABILITY INDICATING RP-HPLC METHOD FOR SIMULTANEOUS DETERMINATION OF CIPROFLOXACIN AND DEXAMETHASONE IN BINARY COMBINATION
}

\author{
${ }^{I}$ SYED NAEEM RAZZAQ, ${ }^{2}$ MUHAMMAD ASHFAQ*, ${ }^{3}$ IRFANA MARIAM, ${ }^{1}$ ISLAM ULLAH KHAN, ${ }^{4} S Y E D$ \\ SALEEM RAZZAQ, ${ }^{2}$ GHULAM MUSTAFA
}

\author{
${ }^{1}$ Department of Chemistry, Government College University, Lahore-54000, Pakistan \\ ${ }^{2}$ Department of Chemistry, University of Gujrat, H.H. Campus, Gujrat-50700, Pakistan \\ ${ }^{3}$ Department of Chemistry, Queen Marry College, Lahore-54000 Pakistan \\ ${ }^{4}$ HPLC Section, BAYER PAKISTAN Pvt. Ltd, Pakistan
}

\begin{abstract}
A simple and isocratic HPLC method with stability indicating nature was developed and then subsequently validated for simultaneous determination of ciprofloxacin and dexamethasone in pharmaceutical formulations, human serum and urine. Best chromatographic separations were attained within run time of 10 minutes using C8 as stationary phase and mixture of phosphate buffer and methanol $(41: 59 \mathrm{v} / \mathrm{v})$ as mobile phase. The mobile phase was flowed at $1.5 \mathrm{~mL}^{-1}$ with detection of both the analytes at $270 \mathrm{~nm}$ using photodiode array detector. Validation of the method was accomplished using specificity, linearity, accuracy, precision, robustness, LOD and LOQ. The method was found linear from 3-21 $\mu \mathrm{g} \mathrm{mL}^{-1}$ for ciprofloxacin $\left(\mathrm{r}^{2} \geq 0.999\right)$ and $1-7 \mu \mathrm{g} \mathrm{mL}^{-1}$ for dexamethasone $\left(\mathrm{r}^{2} \geq\right.$ 0.999 ). The \%age recoveries of ciprofloxacin in spiked human urine and serum were $\geq 99 \%$ and $\geq 85 \%$ respectively, while for dexamethasone they were $\geq 97 \%$ in both matrices. The method proficiently separated the peaks of ciprofloxacin and dexamethasone from all types of interfering substances including degradation products/impurities with purity index $\geq 0.9998$. The method thus was stability-indicating and can be employed for simultaneous analysis of ciprofloxacin and dexamethasone in complex matrices involving multiple components in the mixture.
\end{abstract}

Key words: Liquid Chromatographic, Ciprofloxacin, Dexamethasone, Degradation Products, ICH Guidelines.

\section{1-INTRODUCTION}

Ciprofloxacin

(1-cyclopropyl-6-fluoro-4-oxo-7-(piperazin-1yl)-quinoline-3-carboxylic acid), a well-known antibiotic, is used to relieve bacterial infections of the eyes, corneal ulcers along with some common bacterial attacks. Dexamethasone $(8 S, 9 R, 10 S, 11 S, 13 S, 14 S, 1$ $6 R, 17 R)-9$ - $\quad$ Fluoro-11,17-dihydroxy-17-(2-hydroxyacetyl)-10,13,16trimethyl- $7,8,9,10,11,12,13,14,15,16,17-\quad$ dodecahydro- $3 H$-cyclopenta[ $a$ phenanthren-3-one [Figure 1] a corticosteroid, is used to relieve bacterial ocular infections that require corticosteroid [1]. Many authors have reported a lot of different analytical methods for both drugs individually utilizing differen techniques like HPLC [2-9], spectrophotometry and spectrofluorometric [10-13], titrimetric [14] methods for ciprofloxacin while for dexamethasone different methods involving HPLC, GC and TLC are reported [15-21].
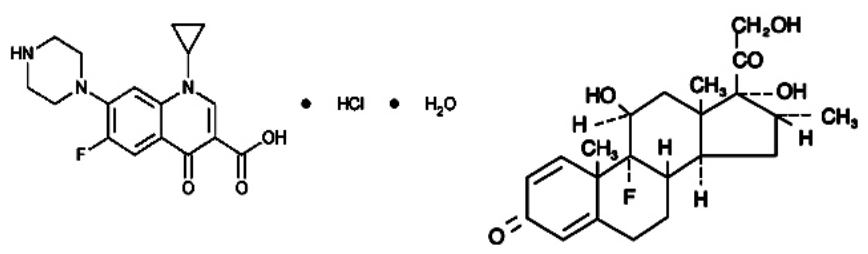

(A)

(B) (B)

Figure 1: Chemical Structure of Ciprofloxacin $\mathrm{HCl}(\mathrm{A})$ and Dexamethasone

Although fixed dose combination (FDC) of both the investigating drugs is available commercially as eye drops, however this FDC has not been listed in any of the common pharmacopoeia. Reviewing the literature resulted in the occurrence of few methods for this FDC [22-23], however no stability indicating HPLC method was found for this FDC. We are involved recently to conduct research relating to method development of FDC of different drugs with varying chemical properties and many of these papers have been reported in the literature [24-36]. In order to fill this knowledge gap, it was attempted to develop and validate HPLC method with stability indicating properties for this FDC (ciprofloxacin and dexamethasone) not only in commercial formulation but also in human serum and urine. We hope, the inclusion of this knowledge in the existing literature will help the pharmaceutical industries in large to maintain the quality of their products containing these active ingredients and also the enforcement agencies in general to monitor the quality of the marketed products.

\section{2-EXPERIMENTAL}

\subsection{Chemicals and Reagents}

Ciprofloxacin $(99.87 \%)$ and dexamethasone $(99.96 \%)$ reference standards were received from Schazoo Zaka Laboratories (Lahore, Pakistan) and were used as such without further refinement. Commercial products (Zoxan D and Ciprodex) containing $3 \mathrm{mg} \mathrm{mL}^{-1}$ ciprofloxacin and $1 \mathrm{mg} \mathrm{mL}^{-1}$ dexamethasone were analyzed during the current research work. All the chemicals used were of either HPLC grade or highest grade available commercially and were used as such. Double distilled water, other liquids used in mobile phase and all the injecting solutions were subject to filtration employing $0.45 \mu \mathrm{m}$ nylon filters (Millipore, USA).

\subsection{Equipment and Chromatographic Conditions}

All the chromatographic work was conducted on LC-20A system (Shimadzu, Japan) using PDA detector at $270 \mathrm{~nm}$. Each time $20 \mu \mathrm{L}$ volume of analytes were injected using the fixed loop and peak areas of ciprofloxacin and dexamethasone were integrated using system built software. For separation, Hypersil BDS C8 column ( 250 X $4.6 \mathrm{~mm}, 5 \mu \mathrm{m})$ was used at room temperature. Pre-mixed mobile phase was used which was prepared by mixing 59:41 v/v ratio of methanol and $0.018 \mathrm{M}$ phosphate buffer $(\mathrm{pH} 3.0)$ and was flowed at $1.5 \mathrm{~mL} \mathrm{~min}^{-1}$. pH 3.0 phosphate buffer was made by dissolving $2.448 \mathrm{~g}$ of potassium dihydrogen phosphate in $1 \mathrm{~L}$ water, followed by $1 \mathrm{~mL}$ triethylamine (TEA) and finally adjustment of the $\mathrm{pH}$ to 3.0 with dilute phosphoric acid.

2.3 Preparation of Stock Solution (A)

To prepare the stock solution (A) of $300 \mu \mathrm{g} \mathrm{mL}-1$ ciprofloxacin and $100 \mu \mathrm{g} \mathrm{mL} \mathrm{m}^{-1}$ dexamethasone respectively, $30 \mathrm{mg}$ ciprofloxacin and $10 \mathrm{mg}$ dexamethasone were accurately weighed and then transferred to $100 \mathrm{~mL}$ volumetric flask. The analytes were sonicated for about 8-10 minutes in small amount of methanol and finally marked to the volume using mobile phase.

2.4 Preparation of Working Standard Solution (B)

The working standard solution was prepared by diluting stock solution (A) to 25 times with mobile phase to get working standard solution (B) of $12 \mu \mathrm{g}$ $\mathrm{mL}^{-1}$ ciprofloxacin and $4 \mu \mathrm{g} \mathrm{mL}^{-1}$ dexamethasone.

2.5 Preparation of Sample Solution

To prepare the sample solution, commercial eye drop was diluted 250 times with mobile phase to get $12 \mu \mathrm{g} \mathrm{mL}^{-1}$ ciprofloxacin and $4 \mu \mathrm{g} \mathrm{mL}$ dexamethasone.

\subsection{Preparation of Human Urine Samples}

Human urine $(50 \mu \mathrm{L})$ was spiked with $50 \mu \mathrm{L}$ stock solution (A), gently mixed for 2 minutes and then centrifuged for 10 minutes at $4000 \mathrm{rpm}$. 80 
$\mu \mathrm{L}$ of this solution was diluted with $920 \mu \mathrm{L}$ of the mobile phase and mixed for 2 minutes to get the final concentration of $12 \mu \mathrm{g} \mathrm{mL}^{-1}$ and $4 \mu \mathrm{g} \mathrm{mL}-1$ for ciprofloxacin and dexamethasone respectively.

\subsection{Preparation of Human Serum Samples}

Proteins were precipitated before the direct injection of human serum into the HPLC system. To precipitate proteins and inject analytes directly, human serum $(200 \mu \mathrm{L})$ was spiked with stock solution $(40 \mu \mathrm{L})$, followed by addition of $760 \mu \mathrm{L}$ mobile phase. The resulting solution was subjected to centrifugation for 10 minutes at $4000 \mathrm{rpm}$ to get protein-free analytes. This results in achieving concentration of $12 \mu \mathrm{g} \mathrm{mL}^{-1}$ ciprofloxacin and $4 \mu \mathrm{g} \mathrm{mL}^{-1}$ dexamethasone.

\subsection{Linearity}

To get the linear calibration curves and to calculate the correlation coefficient, seven mixed standard solutions in the ranges of 3-21 $\mu \mathrm{g} \mathrm{mL}^{-1}(3,6$, $9,12,15,18$ and $\left.21 \mu \mathrm{g} \mathrm{mL}^{-1}\right)$ for ciprofloxacin and $1-7 \mu \mathrm{g} \mathrm{mL}^{-1}(1,2,3,4,5,6$ and $7 \mu \mathrm{g} \mathrm{mL}^{-1}$ ) for dexamethasone were prepared. Triplicate injections of each mixed standard solution were conducted.

\subsection{Accuracy}

To carryon accuracy, standard analytes in mixed mode were spiked in common excipients present in ophthalmic preparations, human urine and serum. Three different levels of solutions ranging from $50-150 \%$ of the nominal concentrations were spiked to the mixture of benzalkonium chloride and $\mathrm{NaCl}$ (in aqueous base), human urine and serum.

\subsection{Precision}

Precision was evaluated in terms of intra-day and inter-day precision. To evaluate, intra-day precision, three different concentrations of standard analytes were injected within same day, whereas for intra-day precision, same solutions (placed in dark) were analyzed singly for three consecutive days. Relative standard deviation of the peak area was then conducted to check the level of precision.

2.11 Specificity (Stress Testing)

ICH recommended stress conditions like acidic, basic, oxidative, thermal and photolytic stresses were applied to demonstrate specificity of the method.

2.11.1. Acid Degradation Studies

To perform acid stress studies, a mixture of stock solution $(1 \mathrm{~mL})$ and 5 $\mathrm{M} \mathrm{HCl}(1 \mathrm{~mL})$ in $25 \mathrm{~mL}$ volumetric flask was kept for 22 hour at $40{ }^{\circ} \mathrm{C} / 75 \%$ $\mathrm{RH}$, followed by neutralizing the excess acid using $5 \mathrm{M} \mathrm{NaOH}$. This was then further marked up to $25 \mathrm{~mL}$ with mobile phase.

2.11.2. Base Degradation Studies

To perform basic stress studies, two separate $25 \mathrm{~mL}$ volumetric flask each containing a mixture of stock solution $(1 \mathrm{~mL})$ and $5 \mathrm{M} \mathrm{NaOH}(1 \mathrm{~mL})$ were kept in environmental test chamber at different environmental conditions. One flask was placed for 16 hours and other for 45 minutes at $40{ }^{\circ} \mathrm{C} / 75 \% \mathrm{RH}$, followed by neutralizing the excess base using $5 \mathrm{M} \mathrm{HCl}$. This was then further marked up to $25 \mathrm{~mL}$ with mobile phase.

\subsubsection{Oxidative Degradation Studies}

To perform oxidative stress studies, a mixture of stock solution $(1 \mathrm{~mL})$ and $6 \% \mathrm{H}_{2} \mathrm{O}_{2}(1 \mathrm{~mL})$ in $25 \mathrm{~mL}$ volumetric flask was kept for 22 hour at $40{ }^{\circ} \mathrm{C} / 75 \%$ $\mathrm{RH}$, followed by marking the volume up to $25 \mathrm{~mL}$ with mobile phase.

2.11.4. Thermal Degradation Studies

To perform thermal stress studies, stock solution $(1 \mathrm{~mL})$ taken in $25 \mathrm{~mL}$ volumetric flask was kept for 22 hour at $40{ }^{\circ} \mathrm{C} / 75 \% \mathrm{RH}$, followed by marking the volume up to $25 \mathrm{~mL}$ with mobile phase.

2.11.5. Photolytic Degradation Studies

To perform photolytic stress studies, stock solution $(1 \mathrm{~mL})$ taken in 25 $\mathrm{mL}$ volumetric flask was kept for 1.25 hours in direct sunlight, followed by marking the volume up to $25 \mathrm{~mL}$ with mobile phase.

\subsection{Robustness}

For the determination of method robustness prearranged deviation in the investigational circumstances was done. For this purpose, slight deviations were deliberately performed in the HPLC operating conditions like composition, rate of flow and buffer solution $\mathrm{pH}$. The effect of these deviations was checked on the separation parameters

2.13 Limit of detection and limit of quantitation

Signal-to-noise $(\mathrm{S} / \mathrm{N})$ ratio approach was adopted to calculate LOD and LOQ. For LOD and LOQ values, solutions of decreasing concentration were prepared by spiking known amounts of analytes into different matrices. The spiked solutions were injected in descending order to determine the $\mathrm{S} / \mathrm{N}$ ratio. For LOQ S/N ratio of 10:1 while for LOD S/N ratio of 3:1 was used.

\section{3-RESULTS AND DISCUSSION}

Development of stability indicating RP-HPLC methods for analysis of drugs in pharmaceutical formulations, human serum and urine received much attention because of their importance in routine quality control, stability analysis and pharmacokinetic studies. In liquid chromatographic analysis, the selection of appropriate chromatographic conditions (stationary phase and mobile phase) is very important because lots of stationary phases and mobile phases can be selected. The chemistry of separating analytes plays a role when selecting appropriate chromatographic conditions. Ciprofloxacin and dexamethasone drugs can be separated through reverse-phase stationary phases because of containing major non-polar groups as well as containing unsaturated $\pi$ electrons as demonstrated in our previous studies $[28,36]$. Polar stationary phases like cyano, can also be used as groups like $(-\mathrm{COOH},-\mathrm{OH}$ or F etc.) are also found in these two analytes.

In this study a simple and precise RP-HPLC method with stability indicating nature was developed to analyze ciprofloxacin and dexamethasone simultaneously. With the purpose to get well resolved/symmetrical and impurity free peaks, changes were made in the mobile phase composition and $\mathrm{pH}$ of mobile phase as well as selection of different polar and non-polar columns with different lengths were used for ciprofloxacin and dexamethasone combination.

3.1 Optimization of Mobile Phase and Stationary Phase

During initial experiments, dexamethasone peaks showed high tailing on C18, Phenyl-2, and Cyano columns but symmetrical/good peak on C8 [28, 36]. However when same conditions were applied to ciprofloxacin using C8 column, tailed peak (tailing factor 1.99) was observed. Later adjustments in the composition of the buffer and methanol as well as $\mathrm{pH}$ of the buffer solution resulted in the separation of both the analytes as well as complete separation from the degradation products. The separation of analytes under different $\mathrm{pH}$ conditions have been shown in Figure 2. On the basis of these results, the final composition of the mobile phase used was, methanol: phosphate buffer $0.018 \mathrm{M}$, pH $3.0(59: 41, \mathrm{v} / \mathrm{v})$ containing $0.1 \%$ TEA that resulted in good/symmetrical peaks at retention times of 3.522 , and 7.628 min, respectively.

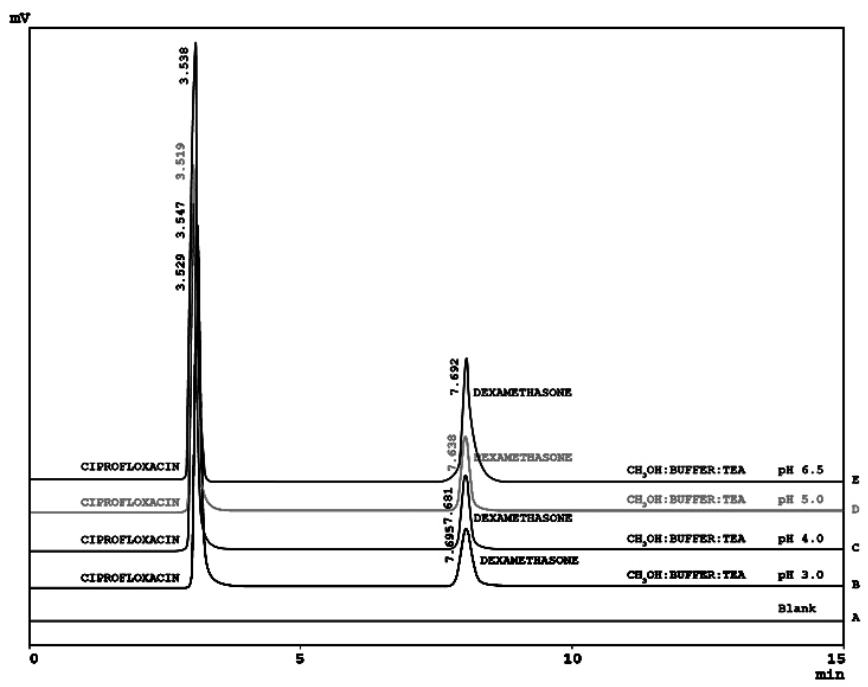

Figure 2: Chromatograms of Ciprofloxacin and Dexamethasone at Different $\mathrm{pH}$

Where (A) blank, (B) Chromatogram of ciprofloxacin and dexamethasone at $\mathrm{pH} 3.0$, (C) Chromatogram of ciprofloxacin and dexamethasone at $\mathrm{pH} 4.0$, (D) Chromatogram of ciprofloxacin and dexamethasone at $\mathrm{pH} 5.0$, and (E) Chromatogram of ciprofloxacin and dexamethasone at $\mathrm{pH} 6.5$, Chromatographic conditions : mobile phase methanol: $0.018 \mathrm{M}$ phosphate buffer $(59: 41, \mathrm{v} / \mathrm{v})$ with $0.1 \%$ TEA, at pH 3.0 or 4.0 or 5.0 or 6.5 , Column BDS Hypersil C8 (250 X $4.6,5 \mu \mathrm{m}$ ), flow rate $1.5 \mathrm{~mL} \mathrm{~min}^{-1}$, injection volume $20 \mu \mathrm{L}$, wavelength $270 \mathrm{~nm}$.

\subsection{Analytical Method Validation}

ICH guidelines were brought into force when validating the analytical method [37]. The description and results of the validation parameters have been summarized below.

To get the linear calibration curves and to calculate the correlation coefficient, seven mixed standard solutions in the ranges of $3-21 \mu \mathrm{g} \mathrm{mL}^{-1}$ (3, $6,9,12,15,18$ and $\left.21 \mu \mathrm{g} \mathrm{mL}^{-1}\right)$ for ciprofloxacin and $1-7 \mu \mathrm{g} \mathrm{mL}-1$ (1, 2, 3, 4 , 5,6 and $7 \mu \mathrm{g} \mathrm{mL}^{-1}$ ) for dexamethasone were prepared. Triplicate injections of each mixed standard solution were conducted. Linear regression equation 
for ciprofloxacin was found to be $\mathrm{Y}=268966 \mathrm{X}+16692$ with correlation coefficient $\geq 0.999$ whereas for dexamethasone, it was $\mathrm{Y}=17341 \mathrm{X}+439.57$ with correlation coefficient $\geq 0.999$.

For LOD and LOQ values, solutions of decreasing concentration were prepared by spiking known amounts of analytes into different matrices. The LOD was $0.169 \mu \mathrm{g} \mathrm{mL} \mathrm{m}^{-1}$ and $0.07 \mu \mathrm{g} \mathrm{mL}^{-1}$ for ciprofloxacin and dexamethasone, respectively whereas LOQ was $0.573 \mu \mathrm{g} \mathrm{mL}^{-1}$ and $0.187 \mu \mathrm{g}$ $\mathrm{mL}^{-1}$ for ciprofloxacin and dexamethasone, respectively.

To carryon accuracy, standard analytes in mixed mode were spiked in common excipients present in ophthalmic preparations, human urine and serum. Three different levels of solutions ranging from $50-150 \%$ of the nominal concentrations were spiked to the mixture of benzalkonium chloride and $\mathrm{NaCl}$ (in aqueous base), human urine and serum. Recoveries of the analytes calculated during the current study are given in Table 1 which witnessed high recoveries.

Table 1. Accuracy of the Proposed HPLC Method.

\begin{tabular}{|c|c|c|c|}
\hline Nature of Sample & $\begin{array}{c}\text { Spiked } \\
\text { Concentration } \\
\left(\mu \mathrm{g} \mathrm{mL}^{-1}\right)\end{array}$ & $\begin{array}{c}\text { Measured } \\
\text { Concentration } \\
\pm \mathrm{RSD}(\%)(\mu \mathrm{g} \\
\left.\mathrm{mL}^{-1}\right)\end{array}$ & $\begin{array}{c}\text { Recovery } \\
(\%)\end{array}$ \\
\hline \multicolumn{4}{|l|}{$\begin{array}{c}\text { Pharmaceutical } \\
\text { Drugs }\end{array}$} \\
\hline \multirow[t]{3}{*}{ Ciprofloxacin } & 6 & $6.02 \pm 0.89$ & 100.33 \\
\hline & 12 & $12.05 \pm 1.14$ & 100.42 \\
\hline & 18 & $18.10 \pm 1.88$ & 100.56 \\
\hline \multirow[t]{3}{*}{ Dexamethasone } & 2 & $2.01 \pm 1.51$ & 100.50 \\
\hline & 4 & $4.03 \pm 1.54$ & 100.75 \\
\hline & 6 & $6.05 \pm 0.59$ & 100.83 \\
\hline \multicolumn{4}{|l|}{ Spiked Serum } \\
\hline \multirow[t]{3}{*}{ Ciprofloxacin } & 6 & $5.15 \pm 2.41$ & 85.83 \\
\hline & 12 & $10.35 \pm 1.24$ & 86.25 \\
\hline & 18 & $15.31 \pm 1.30$ & 85.06 \\
\hline \multirow[t]{3}{*}{ Dexamethasone } & 2 & $2.05 \pm 1.45$ & 102.50 \\
\hline & 4 & $4.00 \pm 1.61$ & 100.00 \\
\hline & 6 & $5.96 \pm 1.88$ & 99.33 \\
\hline \multicolumn{4}{|l|}{ Spiked Urine } \\
\hline \multirow[t]{3}{*}{ Ciprofloxacin } & 6 & $5.98 \pm 2.14$ & 99.67 \\
\hline & 12 & $12.01 \pm 1.68$ & 100.08 \\
\hline & 18 & $18.10 \pm 1.09$ & 100.56 \\
\hline \multirow[t]{3}{*}{ Dexamethasone } & 2 & $2.02 \pm 1.98$ & 101.00 \\
\hline & 4 & $4.01 \pm 0.68$ & 100.25 \\
\hline & 6 & $5.99 \pm 1.39$ & 99.83 \\
\hline
\end{tabular}

Precision was evaluated in terms of intra-day and inter-day precision. To evaluate, intra-day precision, three different concentrations of standard analytes were injected within same day, whereas for intra-day precision, same solutions (placed in dark) were analyzed singly for three consecutive days. Relative standard deviation of the peak area was then conducted to check the level of precision. Results shown in Table 2 agree with high precision.

For the determination of method robustness prearranged deviation in the investigational circumstances was done. For this purpose, slight deviations were deliberately performed in the HPLC operating conditions and results in separation parameters ( $3 a$ and $3 b$ ) were calculated. Observed results revealed the method to be highly robust.
Table 2. Intra-Day and Inter-Day Precision of the Proposed HPLC Method.

\begin{tabular}{|c|c|c|c|}
\hline Drugs & $\begin{array}{c}\text { Actual } \\
\text { Concentration } \\
\left(\mu \mathrm{g} \mathrm{mL}^{-1}\right)\end{array}$ & $\begin{array}{c}\text { Intra-Day } \\
\text { Precision } \\
\text { Measured } \\
\text { Concentration } \pm \\
\text { RSD }(\%)\end{array}$ & $\begin{array}{l}\text { Inter-Day } \\
\text { Precision } \\
\text { Measured } \\
\text { Concentration } \\
\pm \text { RSD }(\%)\end{array}$ \\
\hline \multicolumn{4}{|l|}{$\begin{array}{c}\text { Pharmaceutical } \\
\text { Drugs }\end{array}$} \\
\hline \multirow[t]{3}{*}{ Ciprofloxacin } & 6 & $6.03 \pm 1.45$ & $6.05 \pm 1.89$ \\
\hline & 12 & $12.05 \pm 1.67$ & $11.98 \pm 0.89$ \\
\hline & 18 & $18.07 \pm 0.58$ & $17.94 \pm 0.84$ \\
\hline \multirow[t]{3}{*}{ Dexamethasone } & 2 & $2.01 \pm 1.07$ & $1.99 \pm 1.91$ \\
\hline & 4 & $4.00 \pm 0.81$ & $4.02 \pm 1.90$ \\
\hline & 6 & $6.01 \pm 1.28$ & $5.97 \pm 1.23$ \\
\hline \multicolumn{4}{|l|}{ Spiked Serum } \\
\hline \multirow[t]{3}{*}{ Ciprofloxacin } & 6 & $5.20 \pm 1.61$ & $5.41 \pm 2.26$ \\
\hline & 12 & $10.41 \pm 3.01$ & $10.66 \pm 3.94$ \\
\hline & 18 & $15.33 \pm 1.05$ & $15.70 \pm 1.99$ \\
\hline \multirow[t]{3}{*}{ Dexamethasone } & 2 & $2.01 \pm 1.25$ & $2.04 \pm 2.04$ \\
\hline & 4 & $4.03 \pm 1.07$ & $3.98 \pm 2.03$ \\
\hline & 6 & $6.01 \pm 1.12$ & $5.96 \pm 1.80$ \\
\hline \multicolumn{4}{|l|}{ Spiked Urine } \\
\hline \multirow[t]{3}{*}{ Ciprofloxacin } & 6 & $6.01 \pm 1.49$ & $6.05 \pm 2.16$ \\
\hline & 12 & $12.08 \pm 1.08$ & $12.07 \pm 1.98$ \\
\hline & 18 & $18.09 \pm 1.94$ & $18.09 \pm 1.52$ \\
\hline \multirow[t]{3}{*}{ Dexamethasone } & 2 & $2.00 \pm 1.05$ & $2.00 \pm 1.14$ \\
\hline & 4 & $4.01 \pm 1.21$ & $3.98 \pm 1.19$ \\
\hline & 6 & $6.02 \pm 1.20$ & $6.04 \pm 1.34$ \\
\hline
\end{tabular}

Table 3a. Robustness Study of Ciprofloxacin.

\begin{tabular}{|c|c|c|c|c|}
\hline $\begin{array}{c}\text { Chromatographic } \\
\text { Conditions }\end{array}$ & $\begin{array}{c}\text { Assay } \\
(\%)\end{array}$ & $\begin{array}{c}\mathrm{t}_{\mathrm{R}} \\
(\mathrm{min})\end{array}$ & $\begin{array}{c}\text { Theoretical } \\
\text { Plates }\end{array}$ & Tailing \\
\hline Methanol: Buffer $(61: 39)$ & 102.0 & 3.31 & 3301 & 1.44 \\
\hline Methanol: Buffer $(59: 41)$ & 99.7 & 3.55 & 3347 & 1.44 \\
\hline Methanol: Buffer $(57: 43)$ & 100.8 & 3.61 & 3341 & 1.41 \\
\hline Flow rate $(1.3 \mathrm{~mL} / \mathrm{min})$ & 100.7 & 3.72 & 3399 & 1.42 \\
\hline Flow rate $(1.5 \mathrm{~mL} / \mathrm{min})$ & 101.2 & 3.55 & 3287 & 1.44 \\
\hline Flow rate $(1.7 \mathrm{~mL} / \mathrm{min})$ & 101.1 & 3.31 & 3344 & 1.44 \\
\hline Buffer $(\mathrm{pH} \mathrm{2.8)}$ & 100.9 & 3.55 & 3277 & 1.42 \\
\hline Buffer $(\mathrm{pH} \mathrm{3.0)}$ & 100.2 & 3.55 & 3340 & 1.44 \\
\hline Buffer (pH 3.2) & 101.2 & 3.55 & 3378 & 1.44 \\
\hline
\end{tabular}


Table 3b. Robustness Study of Dexamethasone.

\begin{tabular}{|c|c|c|c|c|}
\hline $\begin{array}{c}\text { Chromatographic } \\
\text { Conditions }\end{array}$ & $\begin{array}{c}\text { Assay } \\
(\%)\end{array}$ & $\begin{array}{c}\mathrm{t}_{\mathrm{R}} \\
(\mathrm{min})\end{array}$ & $\begin{array}{c}\text { Theoretical } \\
\text { Plates }\end{array}$ & Tailing \\
\hline Methanol: Buffer $(61: 39)$ & 101.2 & 7.41 & 5721 & 1.08 \\
\hline Methanol: Buffer $(59: 41)$ & 101.2 & 7.63 & 5774 & 1.08 \\
\hline Methanol: Buffer $(57: 43)$ & 102.0 & 7.78 & 5644 & 1.10 \\
\hline Flow rate $(1.3 \mathrm{~mL} / \mathrm{min})$ & 99.1 & 8.23 & 5594 & 1.10 \\
\hline Flow rate (1.5 mL/min) & 99.5 & 7.63 & 5657 & 1.09 \\
\hline Flow rate (1.7 mL/min) & 100.5 & 7.37 & 5648 & 1.08 \\
\hline Buffer (pH 2.8) & 101.6 & 7.70 & 5788 & 1.09 \\
\hline Buffer (pH 3.0) & 100.7 & 7.63 & 5358 & 1.08 \\
\hline Buffer (pH 3.2) & 100.2 & 7.60 & 5541 & 1.09 \\
\hline
\end{tabular}

To evaluate specificity, ICH prescribed different stress conditions like acid, base, thermal, oxidative and photolytic were applied to both the analytes in mixed form. Chromatograms under different stress environments are shown in Figure 3 whereas the results are summarized in Table 4.

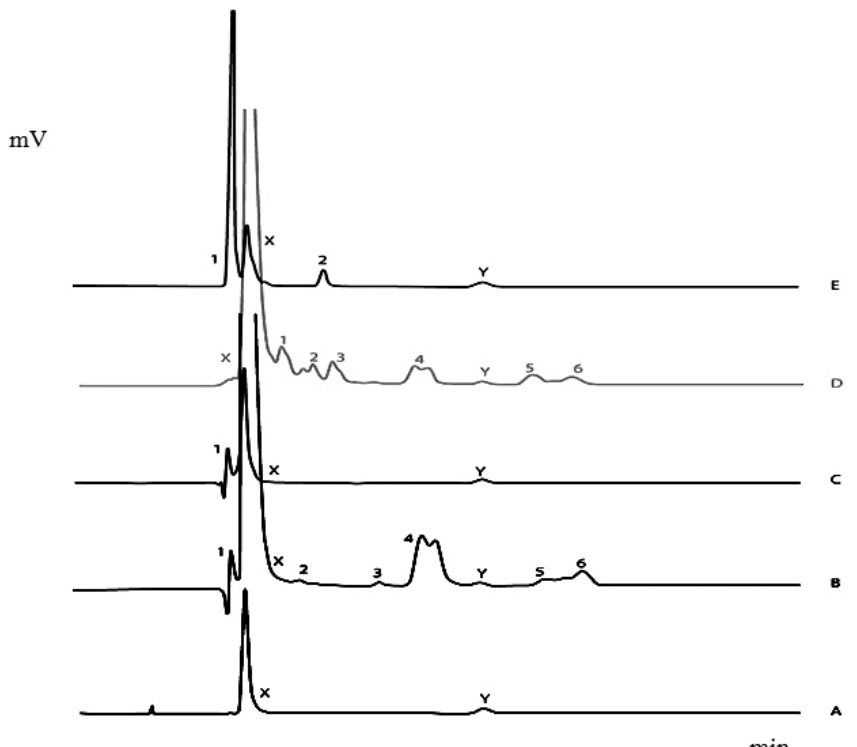

$\min$

Figure 3: Typical Chromatograms of Ciprofloxacin and Dexamethasone under Thermal, Basic, Acidic, Photolytic and Oxidative Stress Conditions.

Where (X) Ciprofloxacin peak, (Y) Dexamethasone peak, (1, 2, 3, 4, 5 and 6) degradation/impurities peaks, (A) chromatogram of thermal stress, (B) chromatogram of basic stress, (C) chromatogram of acidic stress, (D) chromatogram of photolytic stress and (E) chromatogram of oxidative stress Chromatographic conditions: mobile phase methanol: $18 \mathrm{mM}$ phosphate buffer (59:41, v/v), pH 3.0, Column BDS Hypersil C8 $(250$ X 4.6, $5 \mu \mathrm{m})$, flow rate 1.5

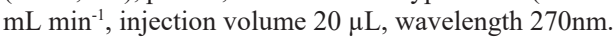

Table 4. Stress Testing Results of Ciprofloxacin and Dexamethasone.

\begin{tabular}{|c|c|c|c|c|}
\hline $\begin{array}{c}\text { Nature of } \\
\text { Stress }\end{array}$ & $\begin{array}{c}\text { Storage } \\
\text { Conditions }\end{array}$ & $\begin{array}{c}\text { Time } \\
(\mathrm{h})\end{array}$ & $\begin{array}{c}\text { Amount of } \\
\text { Ciprofloxacin } \\
\text { remaining } \\
(\%) \pm \mathrm{RSD} \\
(\%)\end{array}$ & $\begin{array}{c}\text { Amount of } \\
\text { Dexamethasone } \\
\text { remaining (\%) } \\
\pm \mathrm{RSD}(\%)\end{array}$ \\
\hline $5 \mathrm{M} \mathrm{HCl}$ & $40^{\circ} \mathrm{C} / 75 \% \mathrm{RH}$ & 22 & $8.7 \pm 2.1$ & $9.0 \pm 1.4$ \\
\hline $\begin{array}{c}\mathrm{NMOH} \\
\mathrm{NaOH}\end{array}$ & $22^{\circ} \mathrm{C} / 52 \% \mathrm{RH}$ & 0.75 & $98.4 \pm 1.2$ & $7.9 \pm 2.5$ \\
\hline $60{ }^{\circ} \mathrm{C} / 75 \% \mathrm{RH}$ & 16 & $9.1 \pm 1.7$ & $8.5 \pm 2.3$ \\
\hline Thermal & $40^{\circ} \mathrm{C} / 75 \% \mathrm{RH}$ & 22 & $9.2 \pm 1.7$ & $8.8 \pm 1.9$ \\
\hline Photolytic & $\mathrm{Sunlight}$ & 1.25 & $84.8 \pm 1.4$ & $9.4 \pm 2.1$ \\
\hline
\end{tabular}

Table 5. Assay Results of Ciprofloxacin and Dexamethasone in Commercial Eye Drops.

\begin{tabular}{|c|c|c|c|}
\hline Eye Drops & Ingredient & $\begin{array}{c}\text { Label value } \\
\left(\mathrm{mg} \mathrm{mL}^{-1}\right)\end{array}$ & $\begin{array}{c}\% \text { Recovery } \\
\pm \mathrm{RSD}(\%)\end{array}$ \\
\hline Zoxan D & Ciprofloxacin & 3 & $100.3 \pm 0.3$ \\
\hline & Dexamethasone & 1 & $99.0 \pm 0.7$ \\
\hline Ciprodex & Ciprofloxacin & 3 & $100.7 \pm 0.1$ \\
\hline & Dexamethasone & 1 & $98.9 \pm 0.7$ \\
\hline
\end{tabular}

The different stresses applied were strong enough the cause degradation for both the analytes. When comparing the stability of both the drugs, it was revealed that dexamethasone was more vulnerable to degradation than ciprofloxacin. When both the drugs were brought in acidic environment, both the drugs showed almost parallel degradation (about $91 \%$ ). Similar degradation results were obtained under basic, thermal and oxidative environment with almost same amount of degradation for both the analytes as was observed under acidic environment. In case of photolytic stress, the dexamethasone showed the same amount of degradation as was achieved in previous stresses environments, however the amount of degradation for ciprofloxacin was only $15 \%$. From all the stress environments in which both drugs were submitted, it was concluded that both the drugs were not stable under the stresses involved. In addition, there was similarity in the degradation profile of both the drugs under photolytic and basic environments.

Further to the amount of degradation, when evaluated for the degradation products generated, it was found that the number of degradation products/ impurities generated in different stress environments were different. For example, the number of impurities produced under acid, photolytic and basic stresses were 6 , followed by two impurities peaks under thermal and oxidative stress. In case of all the stress conditions applied, all the impurities peaks were fully resolved from analyte peaks that prove the method to be stability indicating. The developed method was finally applied to determine both the analytes in their fixed dose combination as well as in spiked human urine and serum. The results presented in Table 5 and shown in figure 4 showed good recoveries and shows its suitability for intended purpose.

\section{4-CONCLUSION}

A simple and isocratic HPLC method with stability indicating nature was developed and then subsequently validated for simultaneous determination of ciprofloxacin and dexamethasone in pharmaceutical formulations, human serum and urine. Validation of the method was accomplished using specificity, linearity, accuracy, precision, robustness, LOD and LOQ. The method was proved simple, do not involve any ion pairing agent and also neither involve the much time taken liquid-liquid extraction not the more expensive solid phase extraction. The method was more efficient to separate both the analytes not only from each other but also from induced degradation products which make its suitability for routine as well as stability and bio-equivalence studies. 


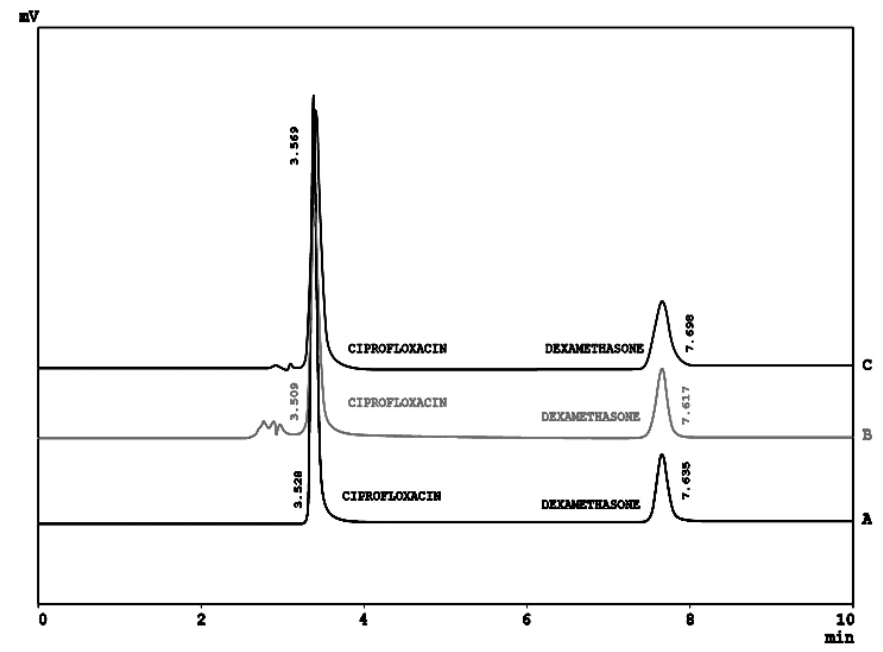

Figure 4: Chromatograms of Ciprofloxacin and Dexamethasone in Pharmaceutical Formulations (A), Human Serum (B) and Urine (C). Chromatographic conditions: mobile phase methanol: $0.018 \mathrm{M}$ phosphate buffer (59:41, v/v) with $0.1 \%$ TEA, at pH 3.0, Column BDS Hypersil C8 (250 X 4.6 , $5 \mu \mathrm{m}$ ), flow rate $1.5 \mathrm{~mL} \mathrm{~min}^{-1}$, injection volume $20 \mu \mathrm{L}$, wavelength $270 \mathrm{~nm}$.

\section{5- REFERENCES}

1.- Reynolds, J.E.F.; Martindale, The Extra Pharmacopoeia, 36th ed. Pharmaceutical Press: London; 2009; p. 243 and 1526.

2.- Predrag, S.; Andreja, M.; Radosav, P.; Sinia, A.; and Valentina, M. Ruggedness testing of an HPLC method for the determination of ciprofloxacin. J. Serb. Chem. Soc. 2005, 70 (7), 979-986.

3.- Marika, K.; Kimiko, T.; Tsutomu, K.; Koichi, N.; and Shigeyuki, N. Determination of ciprofloxacin in plasma and urine by HPLC with ultraviolet detection. J. Clinical Chemistry. 1998, 44 (6), 1251-1255.

4.- Mohsen, A.; Mahnaz, K.; and Abbas, S. Simple high performance liquid chromatographic method for determination of ciprofloxacin in human plasma. Iran. J. Pharm. Res. 2004, 2, 99-101.

5.- Zafar, A. k.; Jamshaid, A. K.; Imran, K.; Ghulam, S. K; Bilal, M.; Tahir, M. $\mathrm{K}$. The development and validation of HPLC-UV method for analysis of ciprofloxacin in serum and aqueous humour. J. Arch. Pharm. Prac. 2011, $2(3), 116-122$

6.- Ranjit, S.; Mukesh, M.; Shailendra, K. S.; Shubhini, S.; and Ram C. G. Simultaneous estimation of ciprofloxacin hydrochloride, ofloxacin, tinidazole and ornidazole by reverse phase high performance liquid chromatography. Eur. J. Anal. Chem. 2009, 4(2), 161-167.

7.- Espinosa, M. A.; Muñoz, A.; González, G. D. HPLC determination of ciprofloxacin, cloxacillin, and ibuprofen drugs in human urine samples. $J$ Sep. Sci., 2006, 29(13), 1969-76.

8.- Sebastian, J. M.; Virginia, H. S.; and James, D. D. 1986. Determination of norfloxacin and ciprofloxacin concentrations in serum and urine by highpressure liquid chromatography. J. Antimicr. Agent. chemo. 1986, 30 (2), 325-327.

9.- Cazedey, E.C.L.; Perez, D.P.; Perez, J.P.; Salgado, H.R.N. A high performance liquid chromatographic assay for ciprofloxacin hydrochloride ophthalmic solution. Chromatographia. 2009, 69, 241-244.

10.- Cazedey, E.C.L.; Bonfilio, R.; Araújo, M.B.; Salgado, H.R.N. A first-derivative spectrophotometric method for the determination of ciprofloxacin hydrochloride in ophthalmic solution. Phys. Chem. 2012 , 2(6), 116-122.

11.- Cazedey, E.C.L.; Salgado, H.R.N. Spectrophotometric determination of ciprofloxacin hydrochloride in ophthalmic solution. Adv. Anal. Chem., 2012, 2(6), 74-79.

12.- Rajia, S. N.; Yeakuty, M. J.; and Kumar, B. S. Development of an assay method for simultaneous determination of ciprofloxacin and naproxen by UV Spectrophotometric method. J. Pharm. Sci. 2011, 4(1), 84-90.

13.- Durmus, Z.; Canel, E.; and Kiliq, E. Spectrofluorimetric assay of ciprofloxacin hydrochloride in tablets. J. Anal. Quant. Cytol. Histol. 2005, 27(3), 162-6.

14.- Basavaiah, K.; and Nagegowsa, P. Titrimetric and spectrophotometric assay methods for ciprofloxacin in pharmaceuticals based on neutralization reaction. J. Natio. Acad. Sci. Lett. 2006, 29(5), 189-194.

15.- Iqbal, M. S.; Shad, M. A.; Ashraf, M. W.; Bilal, M.; and Saeed, M. Development and validation of an HPLC method for the determination of dexamethasone, dexamethasone sodium phosphate and chloramphenicol in presence of each other in pharmaceutical preparations. Chromatographia, 2006, 64(4), 219-222.

16.- Huetos, O.; Ramos, M.; Martín, D. P. M.; San, A. M.; and Reuvers, T. B. Determination of dexamethasone in feed by TLC and HPLC. Analyst. 1999, 124 (11), 1583-7.

17.- Mallinson, E. T.; Dreas, J. S.; Roger, T.; Wilson, A.; and Henry, C. Determination of dexamethasone in liver and muscle by liquid chromatography and gas chromatography/mass spectrometry. J. Agric. Food Chem. 1995, 43 (1), 140-145.

18.- Chen, Q.; Zielinski, D.; Chen, J.; Koski, A.; Werst, D.; and Nowak, S. A. Validated, stability-indicating HPLC method for the determination of dexamethasone related substances on dexamethasone-coated drug-eluting stents. J. Pharm. Biomed. Anal. 2008, 48 (3), 732-738.

19.- Gallego, J. M. L.; and Arroyo, J. P. Simultaneous determination of dexamethasone and trimethoprim by liquid chromatography. J. Pharm. Biomed. Anal. 2002, 30, 1255-1261.

20.- Urban, M. C. C.; Mainardes, R. M.; Gremião, M. P. D. Development and validation of HPLC method for analysis of dexamethasone acetate in microemulsions. Braz. J. Pharma. Sci. 2009, 45 (1), 87-92.

21.- Hyung, W. K. M. D.; Amico, D. J. D.; Korean M. D. Determination of dexamethasone sodium phosphate in vitreous by high performance liquid chromatography. J. ophthalmol. 1995, 9, 79-83.

22.- Rele, R. V.; and Warkar, C. B. Simultaneous determination of ciprofloxacin hydrochloride and dexamethasone in ophthalmic solution by reversed phase high performance liquid chromatography. Asian J. Res. Chem. 2010, 3, 673-677.

23.- Prakash, K.; Sireesha, K. R. Simultaneous determination of ciprofloxacin hydrochloride and dexamethasone sodium phosphate in eye drops by HPLC. E-J. Chem. 2012, 9(3), 1077-1084.

24.- Razzaq, S. N.; Mariam, I.; Khan, I. U.; Ashfaq, M. Development and validation of liquid chromatographic method for gatifloxacin and ketorolac tromethamine in combined dosage form. J. Liq. Chromat. Rel. Technol. 2012, 35, 651-661.

25.- Razzaq, S. N.; Ashfaq, M.; Khan, I. U.; Mariam, I. Development and validation of liquid chromatographic method for moxifloxacin and ketorolac tromethamine in combined dosage form. Quim Nova. 2012, 35, 1216-1221.

26.- Razzaq, S. N.; Ashfaq, M.; Khan, I. U.; Mariam, I. Stability indicating HPLC method for the simultaneous determination of ofloxacin and ketorolac tromethamine in pharmaceutical formulations. Anal. Meth. 2012, 4, 2121-2126.

27.- Razzaq, S. N.; Ashfaq, M.; Khan, I. U.; Mariam, I. Development and validation of liquid chromatographic method for naproxen and esomeprazole in binary combination. J. Chil. Chem. Soc. 2012, 57, 14561459.

28.- Razzaq, S. N.; Ashfaq, M.; Mariam, I.; Khan, I. U.; Razzaq, S. S. Simultaneous RP-HPLC determination of sparfloxacin and dexamethasone in pharmaceutical formulations. Braz. J. Pharm. Sci. 2013, 49, 301-309.

29.- Khan, I. U.; Ashfaq, M.; Razzaq, S. N.; Mariam, I. Simultaneous determination of piroxicam and paracetamol in pharmaceutical formulations using stability indicating HPLC method. J. Liq. Chromat. Rel. Technol. 2013, 36, 1437-1450.

30.- Ashfaq, M.; Ahmad, H.; Khan, I. U.; Mustafa, G. LC determination of rosuvastatin and ezetimibe in human plasma. J. Chil. Chem. Soc. 2013 $58,2177-2181$.

31.- Khan, I. U.; Razzaq, S. N.; Mariam, I.; Ashfaq, M.; Razzaq, S. S. Stability indicating RP-HPLC method for simultaneous determination of gatifloxacin and flurbiprofen in binary combination. Quim Nova, 2014, 37 , 349-354.

32.- Ashfaq, M.; Akhtar, T.; Mustafa, G.; Danish, M.; Razzaq, S. N.; Nazar, M. F. Simultaneous estimation of rosuvastatin and amlodipine in pharmaceutical formulations using stability indicating HPLC method. Braz. J. Pharm. Sci. 2014, 50, 629-638.

33.- Saleem, A.; Anwar, S.; Hussain, T.; Ahmad, R.; Mustafa, G.; Ashfaq M.; Simultaneous Determination of Acetaminophen, Pamabrom and Pyrilamine Maleate in Pharmaceutical Formulations Using Stability Indicating HPLC Assay Method. J. Mex. Chem. Soc. 2015, 59, 93-98.

34.- John, P.; Azeem, W.; Ashfaq, Khan, I. U.; Razzaq, S. N.; Khan, S. U.D. Stability-indicating RP-HPLC method for simultaneous determination of 
methoxsalen and p-aminobenzoic acid in binary combination. Bull. Chem. Soc. Ethiop. 2015, 29, 27-39.

35.- John, P.; Azeem, W.; Ashfaq, Khan, I. U.; Razzaq, S. N. Stabilityindicating RP-HPLC method for simultaneous determination of piroxicam and ofloxacin In binary combination. Pak. J. Pharm. Sci., 2015, 28, 17131721.
36. Razzaq, S. N.; Ashfaq, M.; Khan, I. U.; Mariam, I.; Razzaq, S. S. Azeem, W. Simultaneous determination of dexamethasone and moxifloxacin in pharmaceutical formulations using stability indicating HPLC assay method. Arab. J. Chem. In press. http://dx.doi.org/10.1016/j.arabjc.2014.11.016.

37. ICH (Q2B). Note for guidance on validation of analytical procedures: methodology. International conference on Harmonization, IFPMA, Geneva 1996. 